\title{
COAL MICRONIZATION STUDIES IN VIBRATING MILL IN TERMS OF COAL WATER SLURRY (CWS) FUEL PREPARATION
}

\author{
Jolanta Robak' ${ }^{1}$, Karina Ignasiak' ${ }^{1}$, Michał Rejdak $^{1}$ \\ 1 Institute for Chemical Processing of Coal, Zamkowa 1 St., 41-803 Zabrze, Poland, e-mail: mrejdak@ichpw.pl
}

Received: 2016.12.06

Accepted: 2017.01.02

Published: 2017.03.01

\begin{abstract}
The paper presents the results of coal milling tests in the aspect of slurry fuel preparation. The tests were carried out with the use of vibrating mill with a working chamber of $47.5 \mathrm{dm}^{3}$. The influence of milling time, amount and composition of grinding aids on the degree of fineness and particle size distribution have been investigated. It was found that the efficiency of the grinding process (in this type of milling device) depends primarily on the milling time and the share of grinding aids and - to a lesser extent - on their polydispersity. The study allows to conclude that the grinding time, composition and the share of used grinding aids enable to control the final grain size of coal, which has an impact on apparent viscosity of coal water slurry.
\end{abstract}

Keywords: CWS, slurry fuel, coal water slurry, vibrating mill

\section{INTRODUCTION}

Coal Water Slurry (CWS) is a specific form of solid fuel of finely particulated (grinded) coal and water. Depending on the direction of its use, the solid content (the combustible component) is from approx. 40 to $70 \%$ by weight [Kubica and Smołka 2000]. The attractiveness of this type of fuel is primarily due to its functional properties i.e. liquid form, high energy efficiency (for evaporation of water only $4 \%$ energy is used for CWS with $70 \%$ concentration of coal), decreased environmental nuisance, comparing to combustion of pulverized coal (lower $\mathrm{NO}_{\mathrm{x}}$ and $\mathrm{SO}_{\mathrm{x}}$ emission) and safety in use (reduced risk of explosion). The above-mentioned advantages of CWS fuels, the possibility of independence from petrochemical fuels, wide availability of coal and emphasis on the use of cleaner technologies are driving forces for development of slurry fuel technologies. Currently, the biggest producer and consumer of CWS fuels are China, Japan and Russia [Michalik et al. 2013].

The major parameters characterizing the fuel suspension are: solid phase concentration (concentration of coal in the slurry expressed as weight or volume fraction of dry coal), time stability (resistance to delamination and separation of the dispersed phase from the continuous phase) and rheological properties (viscosity), determining the behavior of suspensions during flow. The parameters are dependent on the susceptibility of coal for the production of aqueous suspensions ("slurrability"), conditioned by natural properties of coal, such as: coalification degree, petrographic composition and surface properties. In addition, they are dependent on slurry fuel preparation process: particle size, solid phase concentration, used additives (stabilizing and dispersion agents) and modification of primary coal properties (ash removal, change of surface properties) [Robak 2008, Mosa et al. 2008]. The factors affecting the quality of the obtained coal - water slurries does not exist separately, and therefore, the properties of coal slurries are the result of interaction between many of them. Besides of the mentioned factors, granulation of solid phase (coal) determines maximum concentration which can be obtained. Granulation and concentration directly influences stability and viscosity of coal-water suspensions [Kubica and Smołka 2000, Colot 2006, Roh et al. 1995]. Investigating viscosity and stability of coal slurries prepared from different hard coals, researchers [Roh et al. 1995] found that these suspensions indicate 
pseudoplasticity i.e. - the viscosity increases with increasing solid phase volume fraction. The viscosity is also dependent on the crushing fineness of the solid phase, i.e. both the average particle diameter and the proportion of individual fractions. For the coals characterized by higher average grain diameter, the lower viscosity values has been noted. Simultaneously, a suspension made from coal characterized by differentiated granulometry (wide range of grain size) had lower viscosity and better stability than the one made from coals with narrow range of grain size. The aforementioned observations are confirmed in other studies [Logosa and Nguyen 1996, Boylu et al. 2004, Aktas and Woodburn 2000]

In principle, the literature information on industrial technology of slurry fuels preparation is limited, however, it suggests that the key element in the production of slurry fuels is deep milling of coal. The system of CWS production in Tampa Electric IGCC consists of two parallel working installations with a capacity up to 60 $\mathrm{T} / \mathrm{h}$ of coal. The main component of the installation are rod mills, where wet coal is continuously supplied and is ground to the desired level. Concentration of solid phase in prepared slurry fuel is approx. 62-68\%. [Clean Coal...2013a, Clean Coal...2013b] The pilot scale technology (UBE Industried Ltd., Japan) for slurry fuel production for gasification in ammonia production plant has been presented in [High concentration...1994]. To obtain proper granulation of solid phase, coalwater slurry was prepared in two-stage milling process in wet conditions. Preliminary crushed coal, after sieving process has been crushed in a ball mill with water addition and then was directed to the rod mill in order to obtain final granu- lation. The solid phase concentration of $67-70 \%$ has been achieved.

In pilot plant for slurry fuel production located in Ruhr Region (Germany) the tube mill with continuous wet coal feeding has been used [Langhoff et al. 1988]. In Pilot plant $(3 \mathrm{t} / \mathrm{h})$ in Saltzgitter [Fiseni 1987], coal is preliminary screened and crushed in ball mill with addition of water and additives. Information about industrial production of the fuel slurry in Russia is usually limited to mentioning the three basic technology nodes: pre-grinding, wet milling and storage [Vodougol'noje toplivo...2013].

The aim of the present study was to evaluate the influence of milling process parameters on the properties of slurry fuels prepared with the use of two Polish steam hard coals.

\section{MATERIALS AND METHODS}

The processes of grinding/milling of solid are carried out in different kinds of mills. The analysis of methods and devices for deep grinding of solids (with particular regard to crushing of coal) showed that vibratory mills are interesting tools in respect to suitability for slurry fuel production. Those devices allow for carrying out the process of grinding in wet and dry conditions. Additionally, they are characterized by a relatively high efficiency and are widely used.

The milling tests of hard coals in terms of slurry fuel preparation were carried out with the use of laboratory scale vibrating mill (batch operation). The scheme of vibrating mill is presented in Figure 1, The basic parameters of mill are presented in Table 1.
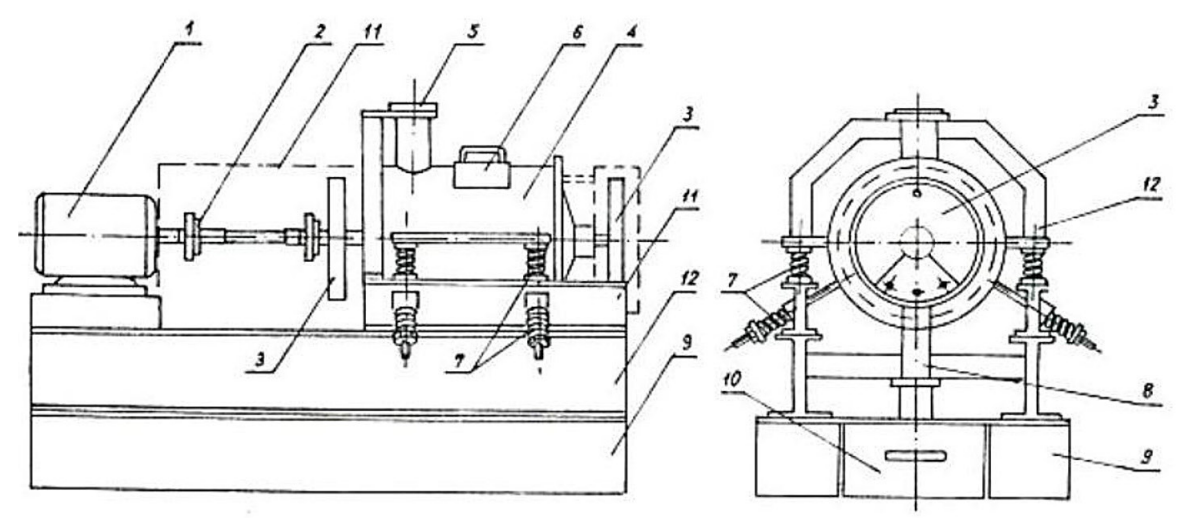

Figure 1. Laboratory scale vibrating mill: 1-engine, 2- clutch, 3 - unbalanced mass, 4 - working chamber, 5 - feeding port, 6 - visor, 7 - springs, 8 - discharging port, 9 - stabilizing construction beam, 10 - material reception container, 11 - protective shield, 12 - construction frame 
Table 1. Characteristics of laboratory vibrating mill

\begin{tabular}{|l|c|}
\hline \multicolumn{1}{|c|}{ Parameter } & Value \\
\hline Working chamber shape & cylindrical \\
Working chamber diameter, $\mathrm{m}$ & 0.4 \\
Working chamber volume, $\mathrm{m}^{3}$ & $47.5 \times 10^{-3}$ \\
Vibration frequency, $\mathrm{Hz}$ & 23.8 \\
Vibration amplitude, $\mathrm{m}$ & $(5-8) \times 10^{-3}$ \\
Oscylation type & circular \\
\hline
\end{tabular}

The mill whose primary part is the working chamber with a capacity of $47.5 \mathrm{dm}^{3}$ mil is an example of a short mill with ratio of length L to diameter $\mathrm{D}$ of 0.95 . The total optimal degree of filling (grinded material and grinding aids) for this type of mill is in the range of 60 to $80 \%$ by volume. In this study, the total filling degree of mill working chamber was $60 \%$, wherein the share of grinding aids was 10,15 and $30 \%$ of working chamber volume. The feed for the mill was a mixture of coal and water, allowing to obtain a suspension with a mass concentration of $50 \%$ by weight (calculated on dried coal). Steel ball as the grinding aids were used (density of $7.8 \mathrm{~kg} / \mathrm{dm}^{3}$, diameter of $9.5 \mathrm{~mm}$ (grinding aids A-10); 14.27 $\mathrm{mm}$ (grinding aids B-15); $20.62 \mathrm{~mm}$ (grinding aids C-20) and $30.16 \mathrm{~mm}$ (grinding aids D-30). The sets of grinding aids (compositions) are presented in Table 2.

Polish steam coals were used for the tests. They were crushed down to obtain a proper granulation recommended for vibrating mills [Drzymała 2007]. Properties of the investigated coals and their particle size distribution is presented in Table 3 and 4.

The assessment of the effect of grinding was carried out based on the results of performed sieve analysis. The samples to analysis were taken at certain periods of time. The analyses were carried out with the use of laser particle size analizer Mastersizer 2000 (Malvern).

The measure of the efficiency of grinding processes is the degree of grinding (milling), defined as the ratio of the size of the grains before and after milling process. Depending on requirements, the average particle size of grains may be mean, modal, harmonic, maximum, minimum or $\mathrm{n}$-rates, i.e. taking into account only $\mathrm{n} \%$ of the population of feed and final products [Planowski et al. 1974]

The efficiency of performed milling tests was evaluated by means of particle size distribution changes and resulting 90\% degree of fineness $\left(i_{(90 \%)}\right)$ which can be calculated with the use of the following formula:

$$
i_{(90 \%)}=\frac{d_{p(90 \%)}}{d_{k(90 \%)}}
$$

where: $d_{p(90 \%)}$ - mean particle size of feed, excluded $10 \%$ of biggest grains [mm],

$d_{k(90 \%)}$ - mean particle size of final product excluded $10 \%$ of biggest grains [mm]. Mean particle size $\left(\mathrm{d}_{\mathrm{p}(90 \%),}, \mathrm{d}_{\mathrm{k}(90 \%)}\right)$ was calculated as mean equivalent size according to the following formulas:

$$
\begin{gathered}
d_{p, k(90 \%)}=\sum_{n-1}^{N} x_{i(90 \%)} d_{z i} \\
d_{z}=\sqrt{a_{1} a_{2}}
\end{gathered}
$$

where: $x_{(90 \%)}-$ mass fraction of size classes excluded $10 \%$ of biggest grains [-],

$d_{p(90 \%)^{\prime}} d_{k(90 \%)}-$ mean particle size before and after milling process excluded $10 \%$ of biggest grains [mm],

$d_{z}-$ equivalent diameter of size fraction [mm],

$a_{1}, a_{2}$ - linear dimensions of the mesh for determined size fraction [mm].

\section{RESULTS AND DISCUSSION}

\section{Milling time}

The proper particle size of coal in slurry fuel is essential to its functional properties. Particle size influences not only the viscosity of the produced fuels but has an impact on the effectivity of atomization and combustion process [KijoKleczkowska 2011]. The size of coal particles also has an impact on stability. In general, the

Table 2. The grinding aids sets used in tests

\begin{tabular}{|c|c|c|c|c|}
\hline \multirow{2}{*}{ Set } & \multicolumn{4}{|c|}{ Share of grinding aids, \% weight } \\
\cline { 2 - 5 } & A-10 & B-15 & C-20 & 25 \\
\hline 1 & 25 & 25 & 25 & 10 \\
\hline 2 & 50 & 30 & 10 & 0 \\
\hline 3 & 50 & 30 & 20 & 100 \\
\hline 4 & 0 & 0 & 0 & \\
\hline
\end{tabular}


Table 3. Properties of investigated coals

\begin{tabular}{|c|c|c|}
\hline Parameter & Coal A & Coal B \\
\hline Ash content $\mathrm{A}^{\mathrm{a}} \%$ & 13.5 & 22 \\
\hline Volatile matter $\mathrm{V}^{\mathrm{V}}$, \% & 29.82 & 25.42 \\
\hline Carbon content $\mathrm{C}_{\mathrm{t}}^{\mathrm{a}}, \%$ & 61.3 & 64.8 \\
\hline Oxygene content. $\mathrm{O}_{d}{ }^{a}, \%$ & 10.59 & 6.44 \\
\hline Vitrinite content $\mathrm{V}, \%$ & 61 & 31 \\
\hline Vitrinite random reflectance $\mathrm{R}, \%$ & 0.46 & 0.79 \\
\hline $\mathrm{HGI}$ & 53 & 53 \\
\hline
\end{tabular}

Table 4. Particle size distribution of the investigated coals

\begin{tabular}{|c|c|c|}
\hline \multirow{2}{*}{ Size classes, $\mathrm{mm}$} & \multicolumn{2}{|c|}{ Mass share, \% } \\
\cline { 2 - 3 } & Coal A & Coal B \\
\hline$>5 \mathrm{~mm}$ & 0.0 & 0.0 \\
$5.0-3.15$ & 0.0 & 0.0 \\
$3.15-2.0$ & 2.4 & 0.4 \\
$2.0-1.0$ & 33.7 & 35.3 \\
$1.0-0.5$ & 26.4 & 25.9 \\
$0.5-0.1$ & 27.2 & 28.1 \\
$<0.1$ & 10.3 & 10.3 \\
$\mathrm{~d}_{\mathrm{p}}, \mathrm{mm}$ & 0.69 & 0.66 \\
$\mathrm{~d}_{\mathrm{p}(90 \%)}, \mathrm{mm}$ & 0.58 & 0.58 \\
\hline
\end{tabular}

maximum coal particle size should not exceed $250 \mu \mathrm{m}$, wherein $70-80 \%$ of particles should have a diameter less than $74 \mu \mathrm{m}$ and mean particle diameter between 20 and $30 \mu \mathrm{m}$ [Boylu et al. 2004, Allen 1984]. Final granulation is dependent on the raw materials used and desired properties of the produced slurry. The apparent viscosity of slurry should be as low as possible, however, the level of 1 Pas is considered to be sufficient [Boylu et al. 2004]. The final viscosity of the produced fuel can be adjusted by using chemical additives [Slaczka and Wasilczyk 2012].

The extension of milling process increases the degree of fineness of ground coal, which is visible on the particle size distribution curves shown in Figure 2. Curves concern the milling process performed at $15 \%$ of working chamber filling with the use of the set 2 of grinding aids (Table 2). Other results of the studies were presented in Tables 5-7. Despite of similar HGI of investigated coals samples (Table 3) and identical condition and time periods of milling process, the degrees of fineness obtained for coal B were higher than those obtained for coal A. After $0.5 \mathrm{~h}$ of milling, in case of coal A the content of grains sized below $100 \mu \mathrm{m}$ is approx. $65 \%$, while for coal B it is approx. $90 \%$. The whole portions of investigated coals A and B were ground below $100 \mu \mathrm{m}$ after 1.5 and 1 hours respectively. In case of coal A, independently to grinding aids set, the mean eqv. particle diameter achieved the level of $\sim 30 \mu \mathrm{m}$ after 1.5 hours of milling. After 1 hour of coal B milling, the mean eqv. particle diameter were below $30 \mu \mathrm{m}$ for each grinding aids sets. With the increment of milling time, decrement of the unitary growths of fineness degree has been noted. It is a premise to search for an optimum between the grinding fineness (influencing the quality of slurry fuel) and milling time which directly affects the costs of the process.

\section{Composition and share of grinding aids}

Apart from milling time, the composition and share of grinding aids, have an influence on milling process effects. Differences in the degree of fineness obtained for coal A and B in a mill filled with grinding aids of different structures are small and more apparent for shorter milling times (Table 5 and 6 ). When only the biggest grinding aids were used (D-30), the lowest fineness degree was obtained. In this case, the mean equivalent diameter $\mathrm{d}_{\mathrm{k}(90 \%)}$ achieved after 2.5 hours of milling was
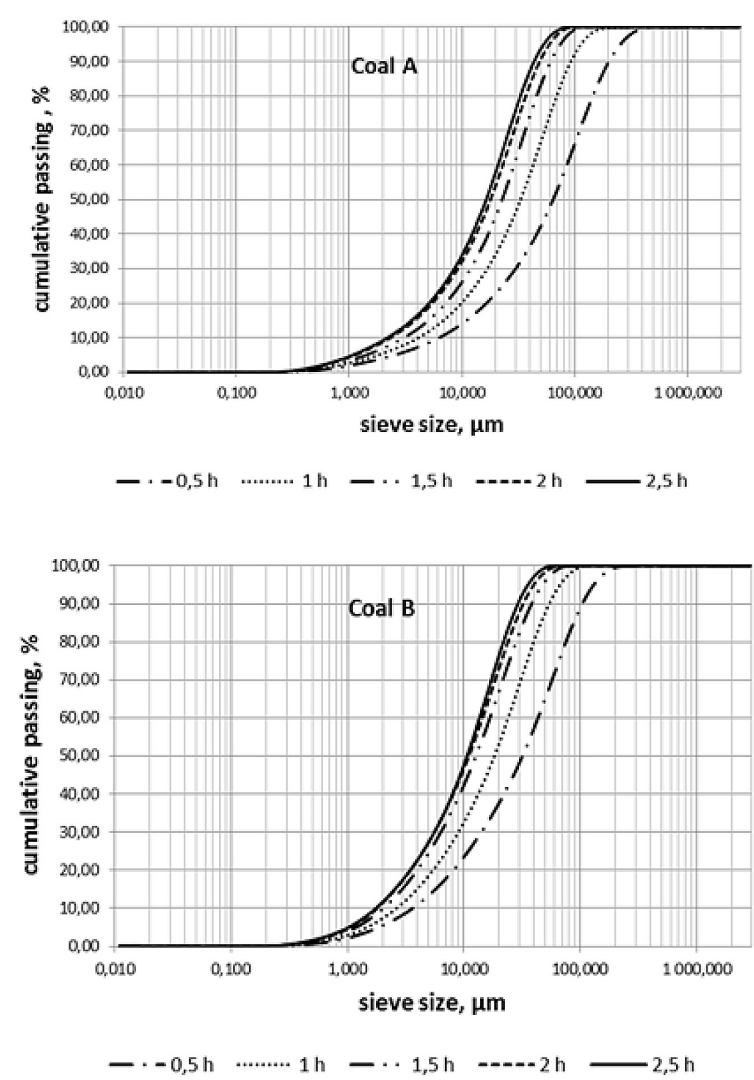

Figure 2. Size distribution of coal samples A and B in relations to milling time in vibrating mill 
Table 5. Mean equivalent diameters $(\mathrm{dk}(90 \%))$ and degrees of fineness $(\mathrm{i}(90 \%))$ of coal A in relation to time of milling and composition of grinding aids

\begin{tabular}{|c|c|c|c|c|c|c|c|c|}
\hline \multirow{2}{*}{ Time of milling, h } & \multicolumn{9}{|c|}{ Set } \\
\cline { 2 - 9 } & \multicolumn{2}{|c|}{1} & \multicolumn{2}{|c|}{2} & \multicolumn{2}{c|}{3} & \multicolumn{2}{c|}{4} \\
\cline { 2 - 9 } & $\mathrm{d}_{\mathrm{k}(90 \%)}, \mu \mathrm{m}$ & $\mathrm{i}_{(90 \%)},-$ & $\mathrm{d}_{\mathrm{k}(90 \%)}, \mu \mathrm{m}$ & $\mathrm{i}_{(90 \%)},-$ & $\mathrm{d}_{\mathrm{k}(90 \%)}, \mu \mathrm{m}$ & $\mathrm{i}_{(90 \%)^{\prime}}$, & $\mathrm{d}_{\mathrm{k}(90 \%)}, \mu \mathrm{m}$ & $\mathrm{i}_{(90 \%)},-$ \\
\hline 0.5 & 98.54 & 5.89 & 87.81 & 6.61 & 85.65 & 6.77 & 75.09 & 7.72 \\
\hline 1.0 & 46.62 & 12.44 & 43.90 & 13.21 & 41.00 & 14.15 & 44.94 & 12.91 \\
\hline 1.5 & 32.37 & 17.92 & 29.80 & 19.46 & 32.19 & 18.02 & 34.21 & 16.95 \\
\hline 2.0 & 26.20 & 22.14 & 23.70 & 24.47 & 25.27 & 22.95 & 27.47 & 21.11 \\
\hline 2.5 & 22.76 & 25.48 & 21.53 & 26.94 & 21.98 & 26.39 & 22.92 & 25.31 \\
\hline
\end{tabular}

Table 6. Mean equivalent diameters $(\mathrm{dk}(90 \%))$ and degrees of fineness $(\mathrm{i}(90 \%))$ of coal B in relation to time of milling

\begin{tabular}{|c|c|c|c|c|c|c|}
\hline \multirow{3}{*}{ Time of milling, h } & \multicolumn{6}{|c|}{ Set } \\
\cline { 2 - 6 } & \multicolumn{2}{|c|}{1} & \multicolumn{2}{c|}{2} & $\mathrm{i}_{(90 \%)},-$ \\
\cline { 2 - 6 } & $\mathrm{d}_{\mathrm{k}(90 \%)}, \mu \mathrm{m}$ & $\mathrm{i}_{(90 \%)},-$ & $\mathrm{d}_{\mathrm{k}(90 \%)}, \mu \mathrm{m}$ & $\mathrm{i}_{(90 \%)},-$ & $\mathrm{d}_{\mathrm{k}(90 \%)}, \mu \mathrm{m}$ & 10.02 \\
\hline 0.5 & 48.75 & 11.90 & 44.85 & 12.93 & 57.89 & 19.83 \\
\hline 1.0 & 26.01 & 22.30 & 24.97 & 23.23 & 29.25 & 28.50 \\
\hline 1.5 & 19.35 & 29.97 & 17.59 & 32.97 & 20.35 & 34.75 \\
\hline 2.0 & 16.62 & 34.90 & 15.19 & 38.18 & 16.69 & 41.73 \\
\hline 2.5 & 13.63 & 42.55 & 14.24 & 40.73 & 13.90 & \\
\hline
\end{tabular}

$22.92 \mu \mathrm{m}$. When the polydisperse bed of grinding aids was used (presence of smaller grinding aids), the empty spaces between them were reduced, thus higher degree of fineness was achieved.

Comparisons between crushing degree of coal $\mathrm{A}$ and $\mathrm{B}$ during the milling in an vibrating mill with polydispersed sets of grinding aids reconfirms the higher grinding ability of coal B in such devices. Contrary to the composition of grinding aids, working chamber filling degree played an important role in milling process. For the same grinding aids compositions, the degree of fineness increased together with working chamber filling degree growth. For set 1 of aids consisting of equal part (by weight) of steel balls used, the growth of filling degree from 10 to 15 and $30 \%$, caused an increase of fineness degree by 39 and $130 \%$ Respectively. The mutual relations between milling time, degree of working chamber filling and achieved degree are clearly visible in Fig. 3 (based on data from table 7). With the use of Statistica software (StatSoft), the response surface regression (RSM) was used to assess the influence of milling time and working chamber filling degree on the achieved degree of fineness. After the elimination of insignificant factors, the final form of equation was formulated:

$$
\begin{aligned}
i_{90}= & 4.778+10.986 \times t-1.86 \times t^{2}+ \\
& +0,016 \times f^{2}+0.274 \times t \times f
\end{aligned}
$$

where: $i_{90}-90 \%$ degree of fineness, $\%$

$t$ - milling time, $\mathrm{h}$

$f$ - working chamber filling degree, $\%$

The determination coefficient of obtained equation $\mathrm{R}^{2}=0.997$ is high and the Fisher-Snedecor value $F=1027$ ( $F$ critical value -3.47 , significance level $\alpha=0.05$ ) which reflect the statistical significance of the obtained equation.

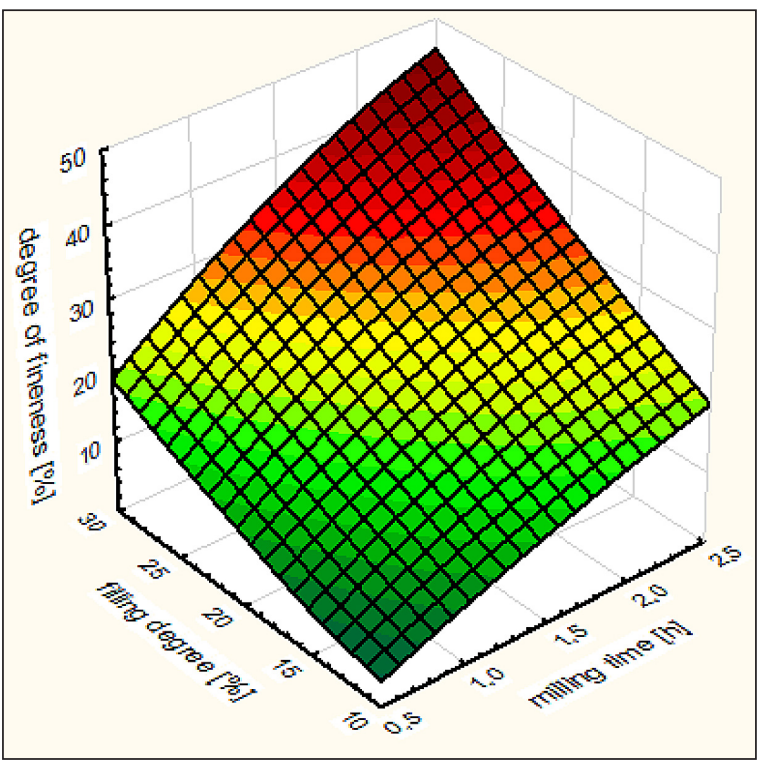

Figure 3. Relationship between milling time, filling degree and achieved degree of fineness 
Table 7. Mean equivalent diameters $(\mathrm{dk}(90 \%))$ and degrees of fineness (i(90\%)) of coal A in relation to time of milling

\begin{tabular}{|c|c|c|c|c|c|c|}
\hline \multirow{3}{*}{$\begin{array}{l}\text { Time of milling, } \\
\mathrm{h}\end{array}$} & \multicolumn{6}{|c|}{ Filling degree of working chamber, \% } \\
\hline & \multicolumn{2}{|c|}{$10 \%$} & \multicolumn{2}{|c|}{$15 \%$} & \multicolumn{2}{|c|}{$30 \%$} \\
\hline & $\mathrm{d}_{\mathrm{k}(90 \%)}, \mu \mathrm{m}$ & $\mathrm{i}_{(90 \%)},-$ & $\mathrm{d}_{\mathrm{k}(90 \%)}, \mu \mathrm{m}$ & $\mathrm{i}_{(90 \%)},-$ & $d_{k(90 \%)}, \mu m$ & $\mathrm{i}_{(90 \%)},-$ \\
\hline 0.5 & 145.07 & 4.00 & 98.54 & 5.89 & 31.09 & 18.66 \\
\hline 1.0 & 75.90 & 7.64 & 46.62 & 12.44 & 20.63 & 28.11 \\
\hline 1.5 & 47.14 & 12.30 & 32.37 & 17.92 & 16.43 & 35.30 \\
\hline 2.0 & 34.22 & 16.95 & 26.20 & 22.14 & 14.38 & 40.33 \\
\hline 2.5 & 29.96 & 19.36 & 22.76 & 25.48 & 12.57 & 46.14 \\
\hline
\end{tabular}

\section{Coal Water Slurry (CWS) evaluation}

One of the most important parameters of slurry fuels is their viscosity which determines fluidity [Boylu et al. 2004, Singh et al. 2016]. Viscosity investigations of slurries prepared during wet milling were carried out. The results were presented in Fig. 4. It is clearly visible that a decrease of mean equivalent particle size caused an increment of apparent viscosity of prepared slur- ries, which is connected with higher surface area of finely grounded particles (Fig.5). In case of coal A, decrease of mean eqv. particle size from 145.07 to $12.57 \mu \mathrm{m}$ ( $\sim 11.5$ times size reduction) caused increase of apparent viscosity from of 0.14 to 1.87 Pas (13.6 times viscosity increase). For coal B a decrease of mean eqv. diameter from 57.89 to $13.9 \mu \mathrm{m}(\sim 4.2$ times size reduction) caused an increase of viscosity from 0.07 to 0.65 Pas (9.3 times viscosity increase). A differ-

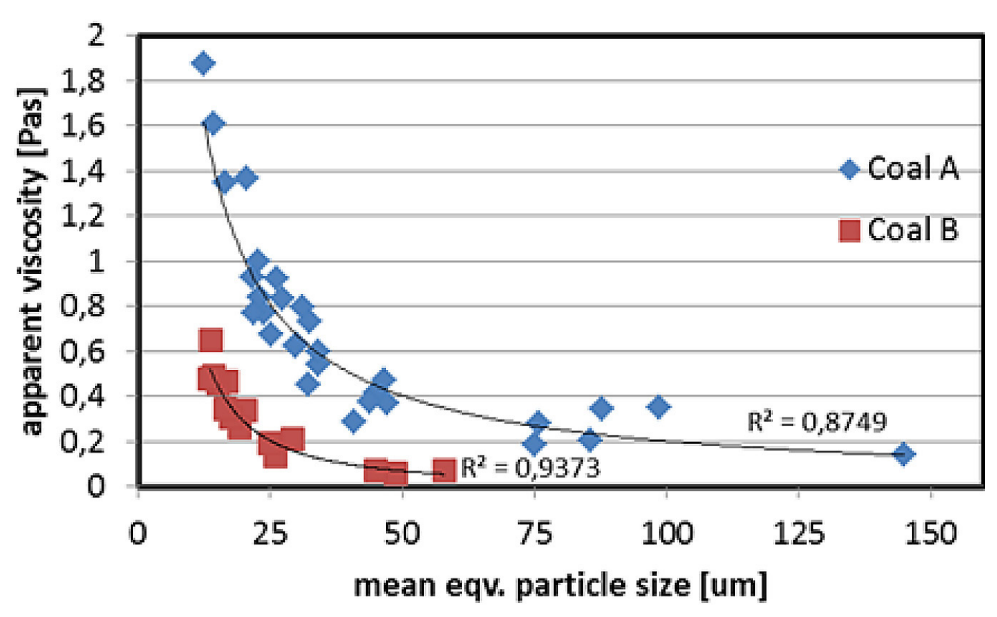

Figure 4. Influence of mean eqv. diameter on apparent viscosity of obtained slurry

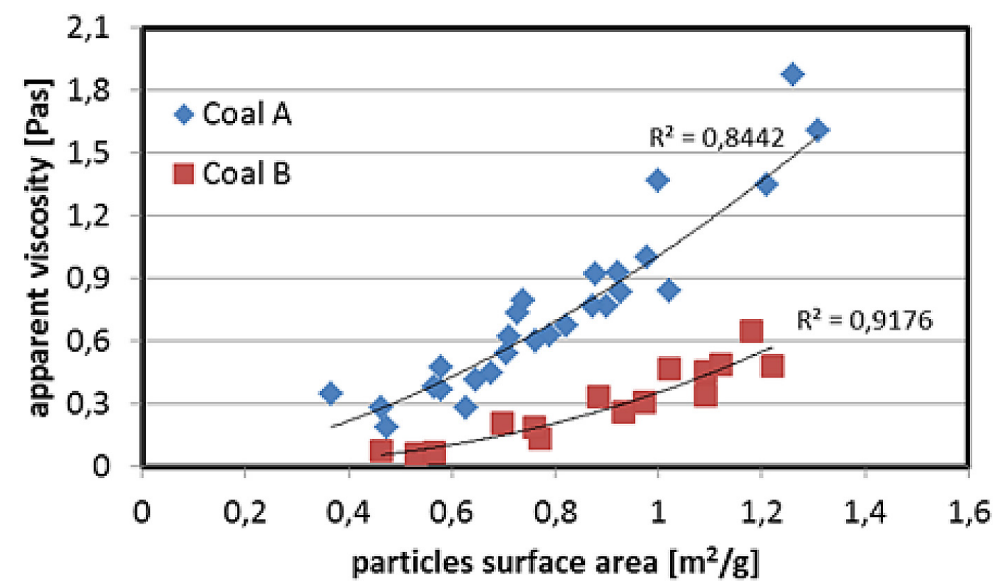

Figure 5. Influence of particle surface area on apparent viscosity of obtained slurry 
ence between coal A and B was noted. For similar value of mean eqv. particle diameter, the apparent viscosity values for slurries prepared from coal $\mathrm{B}$ are approximately three times lower than those for coal A. It can result from different degree of carbon structure ordering and different oxygene content of the investigated coals. Despite of similar volatile matter content, the vitrinite reflectance which reflects the ordering degree of carbon structure (coalification degree) is higher. The structure of coal B characterized by lower oxygene content contains fewer hydrophilic functional groups which can results more hydrophobic character of coal particle surface than those for coal A. Based on the obtained results we can conclude that selected coals are suitable for the production of coal water slurry fuels. Obviously, the final rheological properties of slurry fuels are dependent on the additives used (dispersing, stabilizing agents) whose amounts are related to the required properties of slurry fuels directed to further processing.

\section{CONCLUSIONS}

The results of milling test in vibrating mill with working chamber of $47.5 \mathrm{dm}^{3}$ and evaluation of the obtained coal water slurry fuels has been presented. The variable factors of milling tests were: time of milling, working chamber filling degree and composition of grinding aids. The experiments enabled to rank these factors depending on the degree of their influence on the final result of grinding:

- The main factor determining the degree of fineness is the duration of the process. The times required to obtain a product with a particle size below $100 \mu \mathrm{m}$ from different coals were different. Despite of similar HGI of investigated coals, coal $\mathrm{B}$ required less time than coal A. The time required for adequate fragmentation of the raw materials is approx. 1.5 hours for the coal A and 1 hour of coal B.

- Another factor significantly influencing the achieved fragmentation of the products, is the degree of filling of the working chamber. With an increase of grinding aids amount in working chamber, the efficiency of milling process increased.

- Least significant influence on the efficiency of milling process showed the composition of grinding aids. Only a trend was observed that deeper fragmentation of coal was achieved with the use of polydisperse composition of aids distinguished by smaller diameters.
In aspects of slurry fuel preparation the conclusions are as follows:

1. Decrease of mean equivalent particle size of coal caused an increase of apparent viscosity of slurry fuel which is connected to higher surface area of coal particles

2. Type of used coal has an impact on apparent viscosity of the obtained slurry fuels. For coal characterized by lower oxygene content, the viscosity values was almost three times lower (for similar mean eqv. particle size)

3. It is possible to use Polish steam hard coals to produce slurry fuel with the use of vibrating mill. The final quality of obtained fuel should be fit to the further processing of produced fuel.

\section{Acknowledgment}

The work carried out in the framework of the Research Task No. 3 financed by NCBiR under the Agreement No. SP / E / 3/7708/10

\section{REFERENCES}

1. Aktas, Z., Woodburn, E.T. 2000. Effect of addition of surface active agent on the viscosity of high concentration slurry of a low-rank British coal in water. Fuel Processing Technology. 62, 1-15.

2. Allen J.W., 1984. Burnenrs for coal/water slurry firing. mod.Power. Syst., 43-45.

3. Boylu, F., Dincer, H., Atesok, G. 2004. Effect of coal particle size distribution, volume fraction and rank on the rheology of coal - water slurries. Fuel Processing Technology. 85, 241-250.

4. Clean Coal Technology. DOE/NETL-2004/1207, US Department of Energy. http://netl.doe.gov/ technologies/coalpower/gasification/gasifipedia. Accessed 10 December 2015

5. Clean Coal Technology, Topical Report No 19, US Department of Energy \& Tampa Electric Co. http:// netl.doe.gov/technologies/coalpower/gasification/ gasifipedia). Accessed 10 December 2015

6. Collot, A.G. 2006. Matching gasification technologies to coal properties. Int. J. of Coal Geology. 65, 191-212.

7. Drzymała J. 2007. Mineral Processing - Foundation of theory and practice of minerallurgy. Wroclaw University of Technology.

8. Fiseni, F. 1987. Die hochkonzentrierte Kohle / Wasser - Suspension DENSECOAL. Brennstoff Wärme Kraft. 39, 246-248. 
9. High concentration coal-water mixture for fuel use. 1994. Broschure CADDET IEA OECD, Demo 30.

10. Kijo-Kleczkowska A. 2011. Combustion of coalwater suspensions. Fuel, 90, 865-877.

11. Kubica, R., Smołka, W. 2000. Zawiesinowe paliwa węglowe: rozwój, charakterystyka i perspektywy zastosowania. Gospodarka Paliwami i Energią. 1, 2-8

12. Langhoff, J., Kirschke, H.G., Masuch, H.P., Zagberg, U.. 1988. Kohle-Wasser-Suspension. Erdöl und Kohle - Erdgas - Petrochemie. 41, 166-168

13. Logos, C., Nguyen, Q.D. 1996. Effect of particle size on the flow properties of a South Australian coal - water slurry. Powder Technology. 88, 55-58

14. Michalik A., Hycnar J., Kula H., Fras A.,Sikora L. 2013. Materiały XXVII Konferancji Zagadnienia Surowców Energetycznych i Energii w Gospodarce Krajowej.

15. Mosa, E.S., Saleh, A-H.M., Taha, T. , El-Molla, A.M.. 2008, Effect of chemical additives on flow characteristics of coal slurries. Physicochem. Probl. Miner. Process. 42, 107.

16. Planowski, A.N., Ramm, W.M., Kagan, S.Z., 1974. Procesy i aparaty w technologii chemicznej. WN-T
Warszawa, Chap. 3.

17. Robak, J. 2008. Przygotowanie paliw do zgazowania, in: Borowiecki, T., Kijeński, J., Machnikowski, J., Ściążko, M. (Eds.) Czysta energia. Produkty chemiczne i paliwa $\mathrm{z}$ węgla - ocena potencjału rozwojowego. Wyd. IChPW, Zabrze, 131-138.

18. Roh, N.-S., Shin, D.-H., Kim, D.-CH., Kim, J.-D. 1995. Rheological behaviour of coal -water mixtures. 1. Effects of coal type, loading and particle size. Fuel, 74, 1220-1225.

19. Singh M. K., Ratha D., Kumar S., Kumar D. 2016. Influence of Particle Size Distribution and Temperature on Rheological Behavior of Coal Slurry. International Journal of Coal Preparation and Utilization, 36, 44-54.

20. Slaczka A., Wasilczyk A. 2012. The effect of chemicals on the rheology of highly loaded coal water slurries (CWS), Physicochem. Probl. Miner. Process. 48, 141-148.

21. Vodougol'noje toplivo. Sovriemmiennoje toplivo dla teplo- i elektroenergetiki. Rezime ispolzowanija technologii, http://vodougol.ru. Accessed 10 December 2013 